\title{
Soil contamination in landfills: a case study of a landfill in Czech Republic
}

\author{
D. Adamcová ${ }^{1}$, M. D. Vaverková ${ }^{1}$, S. Bartoň ${ }^{2}$ Z. Havlíček ${ }^{3}$, and E. Břoušková ${ }^{3}$ \\ ${ }^{1}$ Department of Applied and Landscape Ecology, Faculty of Agronomy, Mendel University in Brno, \\ Zemědělská 1, 61300 Brno, Czech Republic \\ ${ }^{2}$ Department of Technology and Automobile Transport, Faculty of Agronomy, Mendel University in Brno, \\ Zemědělská 1, 61300 Brno, Czech Republic \\ ${ }^{3}$ Department of Morphology, Physiology and Animal Genetics, Faculty of Agronomy, Mendel University in Brno, \\ Zemědělská 1, 61300 Brno, Czech Republic
}

Correspondence to: M. D. Vaverková (magda.vaverkova@uake.cz)

Received: 29 September 2015 - Published in Solid Earth Discuss.: 23 October 2015

Revised: 18 January 2016 - Accepted: 18 January 2016 - Published: 11 February 2016

\begin{abstract}
A phytotoxicity test was determined to assess ecotoxicity of landfill soil. Sinapis alba L. was used as a bioindicator of heavy metals. Soil samples $1-8$, which were taken from the landfill body, edge of the landfill body, and its vicinity meet the limits for heavy metals $\mathrm{Co}, \mathrm{Cd}, \mathrm{Pb}$, and $\mathrm{Zn}$ specified in the applicable legislation. $\mathrm{Hg}$ and $\mathrm{Mn}$ threshold values are not established in legislation, but values have been determined for the needs of the landfill operator. For heavy metals $\mathrm{Cr}, \mathrm{Cu}$, and $\mathrm{Ni}$ sample 2 exceeded the threshold values, which attained the highest values of all the samples tested for $\mathrm{Cr}, \mathrm{Cu}$, and $\mathrm{Ni}$. For $\mathrm{Cr}$ and $\mathrm{Ni}$ the values were several times higher than values of the other samples. The second highest values for $\mathrm{Cr}, \mathrm{Cu}$, and $\mathrm{Ni}$ showed sample 6 and 7. Both samples exceeded the set limits. An increase in plant biomass was observed in plants growing on plates with soil samples, but no changes in appearance, slow growth, or necrotic lesions appeared. Ecotoxicity tests show that tested soils (concentration of $50 \%$ ) collected from the landfill body, edge of the landfill body, and its vicinity reach high percentage values of germination capacity of seeds of Sinapis alba L. (101-137\%). At a concentration of 25\%, tested soil samples exhibit lower values of germination capacity - in particular samples 3 to 8 - yet the seed germination capacity in all eight samples of tested soils ranges between 86 and $137 \%$.
\end{abstract}

\section{Introduction}

Land degradation caused by human activities has significant adverse effects on the environments and ecosystems worldwide (Thomaz and Luiz, 2012; Bai et al., 2013; Li et al., 2013; Chen et al., 2015), and solid waste is an important and emerging environmental problem. It was estimated that 0.5 $4.5 \mathrm{~kg}$ per person per day of solid waste is produced in different regions of the world (Bakare et al., 2005; Swati et al., 2014). The most common ways to manage such waste disposal are landfills and incinerators. Actually up to $95 \%$ total municipal solid waste (MSW) collected is disposed of in landfills worldwide (El-Fadel et al., 1997; Swati et al., 2014), and landfilling is the major MSW disposal method used in modern cities (Wong et al., 2015). Landfills were thought to be the safe disposal method of MSW, but this is true only for properly engineered landfill sites. An engineered landfill site allows final disposal of solid waste in a secure manner by minimizing the impacts on the environment as modern landfills are often lined with layers of absorbent material and sheets of plastic to keep pollutants from leaking into the soil and water (Swati et al., 2014).

The improper management of waste disposal raises public concern over potential harmful effects to local communities and the environment. These concerns probably have become more pragmatic when recent intensive studies demonstrated increased human health risk caused by exposure to toxic chemicals, such as dioxins and related compounds, and 
heavy metals in these dumping sites (Agusa et al., 2003; Minh et al., 2003). Landfills containing hazardous materials are under critical observation today for potential hazards, resulting in the need for thorough risk analyses along with the soil and groundwater that have been contaminated with chemicals leaching from landfills. Several reports have been published which are documented on the leachate characterization and its effect on groundwater pollution (Boels and Fleming, 1993), but little information is available on the effect of landfills on soil contamination (Hernández et al., 1996) and its toxicological effects.

Soil is the key part of the Earth system as it control the hydrological, erosional, biological, and geochemical cycles. The soil system also offers goods, services, and resources to humankind (Keesstra et al., 2012; Mol and Keesstra, 2012; Berendse et al., 2015; Brevik et al., 2015; Decock et al., 2015; Smith et al., 2015). This is why it is necessary to research how soils are affected by the use by human societies. Pollution is one of those damaging human activities, and we need more information and assessment of land pollution (Kardanpour et al., 2015; Mahmoud and El-Kader, 2015; Riding et al., 2015; Roy and Mcdonald, 2015; Sacristánet al., 2015; Wang et al., 2015).

Land and soil pollution by heavy metals has become a critical environmental concern due to its potential adverse ecological effects. Heavy metals occur naturally at low concentrations in soils. However, they are considered soil contaminants due to their widespread occurrence, as well as their acute and chronic toxicity (Youn-Joo, 2004).

More recently high concentrations of heavy metal(loid)s, such as $\mathrm{As}, \mathrm{Cd}, \mathrm{Cu}, \mathrm{Pb}$, and $\mathrm{Zn}$ in soils, have often been reported in a number of countries. For example, significant adverse impacts of As on human health have been recorded in Bangladesh, India, and China; it is claimed that millions of people are potentially at risk from As poisoning (Bhattacharya et al., 2012). Similarly, Cd accumulation in the offal of grazing animals in New Zealand and Australia made it unsuitable for human consumption and affected access of meat products to overseas markets (Loganathan et al., 2008). Similarly, there have been concerns about urban development of horticultural sites which contained toxic levels of metal(loid)s such as $\mathrm{As}, \mathrm{Cu}$, and $\mathrm{Pb}$ in soils resulting from excessive use of fungicides and herbicides that are rich in these metal(loid)s (Pietrzak and Uren, 2011).

Plants can be used as bioindicators for toxicity assessment in aquatic and terrestrial ecosystems (Gorsuch et al., 1991). The present research aimed at assessing the soil pollution at a landfill site (in operation) and in the vicinity of a MSW landfill site. The main objective of this study was characterization of soil samples issued from a landfill located near Klatovy, in south-western Czech Republic, in relation to their content of heavy metals. The other objective was to recommend some sensitive plants to assess the phytotoxicity effect on one vegetal species. White mustard (Sinapis alba L.) was selected as the test plant species due to its sensitivity to a wide range of contaminants. To assess phytotoxicity of landfill soil a laboratory study was conducted.

\section{Material and methods}

\subsection{Site description}

The investigated landfill (Štěpánovice, $49^{\circ} 26^{\prime} 15.934^{\prime \prime} \mathrm{N}$, $13^{\circ} 16^{\prime} 55.352^{\prime \prime} \mathrm{E}$, ca. $405 \mathrm{~m}$ a.s.l.) is located in Pilsen Region, western Czech Republic. It started operating in 1996 with an authorized volume of $569000 \mathrm{~m}^{3}$; at the moment, it is being used to dispose mixed municipal waste. The landfill was formed by three sub-landfills: landfill A (closed in 2003, area $8750 \mathrm{~m}^{2}$ ); landfill B (working from 2003, area $26000 \mathrm{~m}^{2}$ ); landfill $\mathrm{C}$ (which will work after closing part $\mathrm{B}$ ). The total volume of both (A, B) parts of the landfill is 289000 $\mathrm{m}^{3}$. Planned service life of the facility is up to year 2018 (Vaverková and Adamcová, 2014a).

Every day, up to $37.5 \mathrm{t}$ of waste is authorized for landfilling after careful analysis: the disposed waste includes municipal solid, non-hazardous wastes and the material for landfill cover. Wastes may include scraps of paper, plastics and metals, packing, used tires, textile products, building materials, ashes from MSW incinerators, polluted terrain from environment reclamation, etc. Particular details of waste composition, waste quantity stored in the landfill, and landfill gas management are not presented in this article. Detailed information and data were described in other articles (Vaverková and Adamcová, 2014a, b, c).

The landfill site is located over an impermeable natural clay layer; bottom and side boundaries may vary according to the period of cultivation. However, they generally include several protective layers, such as a compact clay layer $(100 \mathrm{~cm})$, geotextile membranes, gravel $(50 \mathrm{~cm})$, geomembranes $(2.5 \mathrm{~mm})$, non-woven fabric $\left(1200 \mathrm{~g} \mathrm{~m}^{-2}\right)$, and pulper products.

Landfill covers (top and side) are formed by a waste layer (terrain) to stabilize the surface, drainage systems, compact clay $(20 \mathrm{~cm})$, soil bentonite, and a vegetative soil layer (up to $100 \mathrm{~cm}$ ). A grassy mantle and/or forestation with local vegetation will complete the recovery of the environment after closing of each parcel. Systems for leachate treatment, as well as gas recovery, collection, and treatment are in operation. The landfill is situated in the north part of widely opened valley directed towards W-E. The landfill is surrounded to the $\mathrm{N}$ and $\mathrm{S}$ by a vegetation belt dominated by Pinus sylvestris. The hilly landscape in the western part of the study area is used for agriculture, as well as the eastern lowland. The climate of the area is typically inland, with mean annual rainfall over $582 \mathrm{~mm}$ and mean annual temperature of $8.0^{\circ} \mathrm{C}$ (Vaverková and Adamcová, 2016). 


\subsection{Sample collection}

Soil samples were collected from landfill site at a depth of $10 \mathrm{~cm}$ (Fig. 1) in 2014. They were collected in sterilized plastic containers. Freeze and grounded soil samples were homogenized by sieving them through a stainless steel $0.2 \mathrm{~mm}$ sieve, and they were stored in sealed containers at $-4{ }^{\circ} \mathrm{C}$ until analysis. The materials were analysed for the content of heavy metals $(\mathrm{Hg}, \mathrm{Cd}, \mathrm{Pb}, \mathrm{Cu}, \mathrm{Zn}, \mathrm{Co}, \mathrm{Ni}, \mathrm{Cr}, \mathrm{Mn})$. The examined samples were brought to the testing laboratory (Department of Chemistry and Biochemistry, Faculty of Agronomy, Mendel University in Brno) for analyses.

Figure 1 provides sampling points where soil samples were collected. In total eight sampling points were determined. Samples collected from sampling points 6,7 , and 8 were used as blind samples. Samples from sampling points 4 and 5 were collected directly from the landfill body, and samples 1, 2, and 3 were taken from the edge of the landfill body. The allocations of sampling sites were chosen on the basis of the authors' decision and on the grounds of mutual comparison of the landfill body and its borders with the nearest vicinity of the landfill (agriculturally utilized soil and forests).

\subsection{Sample processing and chemical analysis}

A microwave digestion (Ethos SEL, Milestone, Italy) was used for isolation of analytes from solid samples. Soil samples were air-dried and sieved. A fraction $<2 \mathrm{~mm}$ was used for the analysis; $200 \pm 0.1 \mathrm{mg}$ of dried and homogenized soil samples was used for partial digestion in the microwave oven using $3 \mathrm{~mL}$ of concentrated $\mathrm{HNO}_{3}$ and $9 \mathrm{~mL}$ of concentrated $\mathrm{HCl}$ at $200{ }^{\circ} \mathrm{C}$ and $1000 \mathrm{~W}$ for $30 \mathrm{~min}$. The soil digests were adjusted to the final volume of $25 \mathrm{~mL}$ with deionized water.

An electrothermal atomic-absorption spectrometer (AAS ZEEnit 60, Analytic Jena, Germany equipped with Zeeman correction) was used under the recommended conditions specified by the manufacturer for determination of $\mathrm{Cd}(228.8 \mathrm{~nm}), \mathrm{Pb}(283.3 \mathrm{~nm}), \mathrm{Co}(240.7 \mathrm{~nm})$, and $\mathrm{Cr}$ $(359.3 \mathrm{~nm})$. The wavelengths are given in parentheses. As a modifier, $1 \% \mathrm{Pd} / \mathrm{Mg}\left(\mathrm{NO}_{3}\right)_{2}$ was used.

Flame atomic-absorption spectrometer (AAS ZEEnit 60, Analytic Jena, Germany equipped with Zeeman correction) was used under the recommended conditions specified by the manufacturer for determination of $\mathrm{Cu}(324.7 \mathrm{~nm}), \mathrm{Zn}$ $(213.8 \mathrm{~nm}), \mathrm{Ni}(232.0 \mathrm{~nm})$, and $\mathrm{Mn}(279.5 \mathrm{~nm})$. Acetyleneair flame was used for determination of analytes. The wavelengths are given in parentheses.

Total mercury content in soil samples was measured by one purpose atomic absorption spectrometer AMA 254 (Advanced Mercury Analyzer) controlled by WinAMA software (both Altec, Prague, Czech Republic). The homogenized solid samples were weighted $(100 \pm 0.1 \mathrm{mg})$ into pre-cleaned combustion boats and inserted into the AMA254 analyzer. During analysis the sample was dried at $120^{\circ} \mathrm{C}$ for $90 \mathrm{~s}$ and thermally decomposed at $550{ }^{\circ} \mathrm{C}$ for $180 \mathrm{~s}$ under an oxygen flow. Selectively trapped mercury was subsequently released from the gold amalgamator by a brief heat-up and finally quantified (measuring cycle, $60 \mathrm{~s}$ ) as $\mathrm{Hg}_{0}$ by the cold-vapour AAS technique at $253.65 \mathrm{~nm}$.

LODs (limits of detection) of methods were 0.1 for $\mathrm{Hg}$, 0.02 for $\mathrm{Cd}, 0.38$ for $\mathrm{Pb}, 3.08$ for $\mathrm{Cu}, 3.70$ for $\mathrm{Zn}, 4.92$ for $\mathrm{Co}, 9.00$ for $\mathrm{Ni}, 0.70$ for $\mathrm{Cr}$, and $12.10 \mu \mathrm{g} \mathrm{kg}^{-1}$ for $\mathrm{Mn}$. The results were in good agreement with the certified values.

\subsection{Test plant species}

The test species were white mustard (Sinapis alba L.). They were selected because they are known to be sensitive to a board range of chemicals. White mustard is ideal for studying soils and soil extracts (Gerencsér et al., 2010; OECD Guideline 208 for the Testing of Chemicals, 2003). Seeds were surface-sterilized by soaking for $2 \mathrm{~min}$ in a commercial sodium hypochlorite $(2 \%)$ solution to which a few drops of Tween-20 had been added. Then they were rinsed twice in sterile distilled water. Damaged or empty seed hulls were discarded.

\subsection{Phytotoxicity test}

The earthen pot experiment was performed under laboratory conditions. The earthen pots (height of $10 \mathrm{~cm}$ and a diameter of $11 \mathrm{~cm}$ ) were loosely filled with $200 \mathrm{~g}$ of medium. Then 100 seeds of white mustard were scattered onto the surface, covered with thin layer of silica sand, and covered with a glass plate (to avoid evaporation). The possible toxicological effect was assessed according to CSN EN 13432 on growth of dicotyledonous plants. The medium was specialized soil for germination and plant growth, enriched with soil samples $(25 \%, 50 \% w / w)$. Reference soil was composed of peat and silica sand. Plants were grown under controlled conditions for 21 days. Humidity at level of $70 \pm 25 \%$ of water absorption capacity was maintained to be constant. The toxicity tests were conducted at ambient laboratory temperature of $22 \pm 10^{\circ} \mathrm{C}$, and continuous light was used. Values obtained from two simultaneously conducted experiments were averaged and presented (germination capacity, plant biomass).

\section{Results and discussion}

From the chemical analysis of solid samples with atomic absorption, the leaching values of metals varied over a wide range as follows: $\mathrm{Hg}\left(0.0300-0.0663 \mathrm{mg} \mathrm{kg}^{-1}\right), \mathrm{Cd}(0.0600$ $\left.0.2044 \mathrm{mg} \mathrm{kg}^{-1}\right), \mathrm{Pb}\left(2.5703-8.5287 \mathrm{mg} \mathrm{kg}^{-1}\right), \mathrm{Cu}(32.43-$ $\left.51.24 \mathrm{mg} \mathrm{kg}^{-1}\right)$, Zn $\left(25.67-41.97 \mathrm{mg} \mathrm{kg}^{-1}\right)$, Co $(2.953-$ $\left.12.712 \mathrm{mg} \mathrm{kg}^{-1}\right)$, Ni (32.65-140.03 mg kg-1), Cr (64.06$\left.190.73 \mathrm{mg} \mathrm{kg}^{-1}\right)$, and $\mathrm{Mn}\left(547.52-701.39 \mathrm{mg} \mathrm{kg}^{-1}\right)$. The metal leaching values found in this study are shown in Table 1 . 


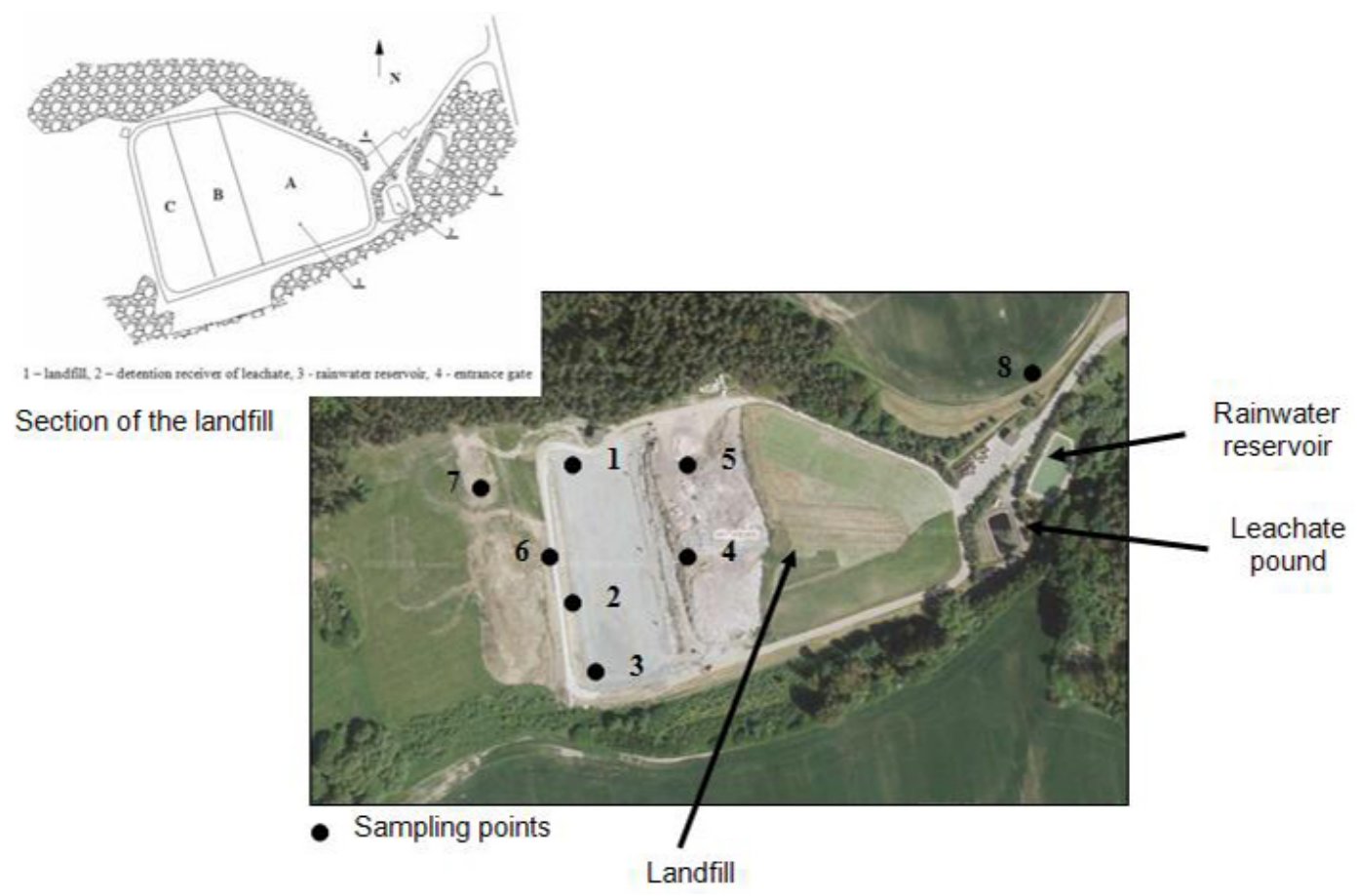

Figure 1. Map of Štěpánovice landfill and sampling points.

Table 1. Content of heavy metals in examined soil samples.

\begin{tabular}{|c|c|c|c|c|c|c|c|c|c|}
\hline Sample & $\begin{array}{r}\mathrm{Hg} \\
\left(\mathrm{mg} \mathrm{kg}^{-1}\right)\end{array}$ & $\begin{array}{r}\mathrm{Cd} \\
\left(\mathrm{mg} \mathrm{kg}^{-1}\right)\end{array}$ & $\begin{array}{r}\mathrm{Pb} \\
\left(\mathrm{mg} \mathrm{kg}^{-1}\right)\end{array}$ & $\begin{array}{r}\mathrm{Cu} \\
\left(\mathrm{mg} \mathrm{kg}^{-1}\right)\end{array}$ & $\begin{array}{r}\mathrm{Zn} \\
\left(\mathrm{mg} \mathrm{kg}^{-1}\right)\end{array}$ & $\begin{array}{r}\text { Co } \\
\left(\mathrm{mg} \mathrm{kg}^{-1}\right)\end{array}$ & $\begin{array}{r}\mathrm{Ni} \\
\left(\mathrm{mg} \mathrm{kg}^{-1}\right)\end{array}$ & $\begin{array}{r}\mathrm{Cr} \\
\left(\mathrm{mg} \mathrm{kg}^{-1}\right)\end{array}$ & $\begin{array}{r}\mathrm{Mn} \\
\left(\mathrm{mg} \mathrm{kg}^{-1}\right)\end{array}$ \\
\hline 1 & 0.0300 & 0.0670 & 6.5554 & 34.07 & 25.67 & 4.888 & 39.13 & 69.99 & 689.55 \\
\hline 2 & 0.0311 & 0.1446 & 2.5703 & 58.62 & 34.20 & 12.712 & 140.03 & 190.73 & 608.67 \\
\hline 3 & 0.0343 & 0.1446 & 5.1769 & 39.37 & 31.51 & 2.953 & 32.65 & 65.92 & 547.52 \\
\hline 4 & 0.0663 & 0.1576 & 8.5287 & 34.25 & 39.29 & 5.825 & 36.94 & 64.06 & 610.10 \\
\hline 5 & 0.0403 & 0.1343 & 5.1095 & 32.43 & 33.93 & 10.284 & 33.11 & 70.10 & 584.58 \\
\hline 6 & 0.0386 & 0.2044 & 5.4088 & 51.24 & 41.97 & 6.874 & 44.05 & 86.69 & 625.12 \\
\hline 7 & 0.0459 & 0.0600 & 5.0800 & 43.80 & 32.10 & 5.375 & 42.76 & 74.85 & 661.00 \\
\hline 8 & 0.0312 & 0.1471 & 4.1255 & 50.20 & 31.68 & 5.469 & 37.59 & 69.94 & 701.39 \\
\hline
\end{tabular}

Figure 2 shows the graphically evaluated results of heavy metal content in individual soil samples, with marked limit values for those heavy metals for which the limits are established in the Decree of the Ministry of the Environment of the Czech Republic no. 13/1994 Coll., as amended, laying down the details of agricultural land fund protection.

For heavy metals $\mathrm{Cd}, \mathrm{Pb}, \mathrm{Zn}$, and $\mathrm{Co}$, none of the eight examined soil samples exceeded the limits specified in the decree, as shown by the charts listed in Fig. 3. For $\mathrm{Cu}$, $\mathrm{Ni}$, and $\mathrm{Cr}$ some of the collected soil samples exceeded the limits established in the relevant legislation. For $\mathrm{Cu}$, the maximum limit for this heavy metal is $50 \mathrm{mg} \mathrm{kg}^{-1}$. Samples that exceeded the limit for $\mathrm{Cu}$ were as follows: sample $2\left(58.62 \mathrm{mg} \mathrm{kg}^{-1}\right)$, sample $6\left(51.24 \mathrm{mg} \mathrm{kg}^{-1}\right)$, and sample $8\left(50.20 \mathrm{mg} \mathrm{kg}^{-1}\right)$. For $\mathrm{Ni}$, the maximum limit is set at $25 \mathrm{mg} \mathrm{kg}^{-1}$. This threshold value was exceeded by all eight soil samples; the highest value was measured in sample $2\left(140.03 \mathrm{mg} \mathrm{kg}^{-1}\right)$. The maximum allowed value for $\mathrm{Cr}$ (40 $\mathrm{mg} \mathrm{kg}^{-1}$ ) was exceeded by all eight samples, with sample 2 showing the highest value $\left(190.73 \mathrm{mg} \mathrm{kg}^{-1}\right)$. No limit values are established for $\mathrm{Mn}$ and $\mathrm{Hg}$ presence in the soil. After the levels of heavy metals in collected soil samples were determined, the phytotoxicity was tested.

Fourteen days from the establishment of the experiment, sprouts and the number of growing plants occurring in the earthen pots were counted. The data were plotted into tables, and photographs were taken to document the course of the experiment. Germination capacity and growth of white mustard is shown in Fig. 3. Twenty-one days from the establishment of the experiment, the counting of sprouts and growing plants was repeated, the results recorded, and photographs taken. 

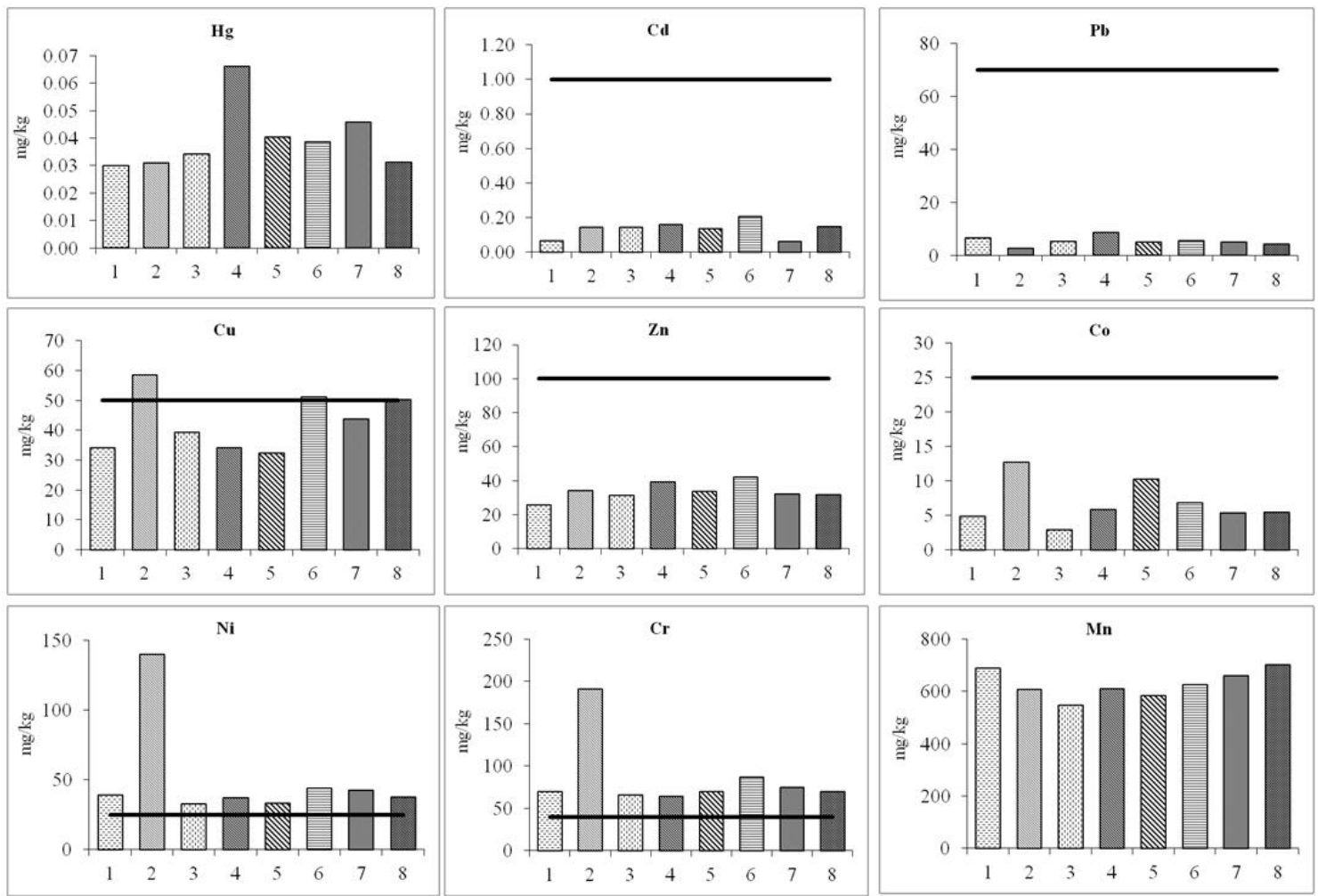

Figure 2. Content of heavy metals in examined soil samples with marked limit values set in the Decree no. 13/1994 Coll. Mn, Hg - no threshold values are set in the Decree no. 13/1994 Coll.
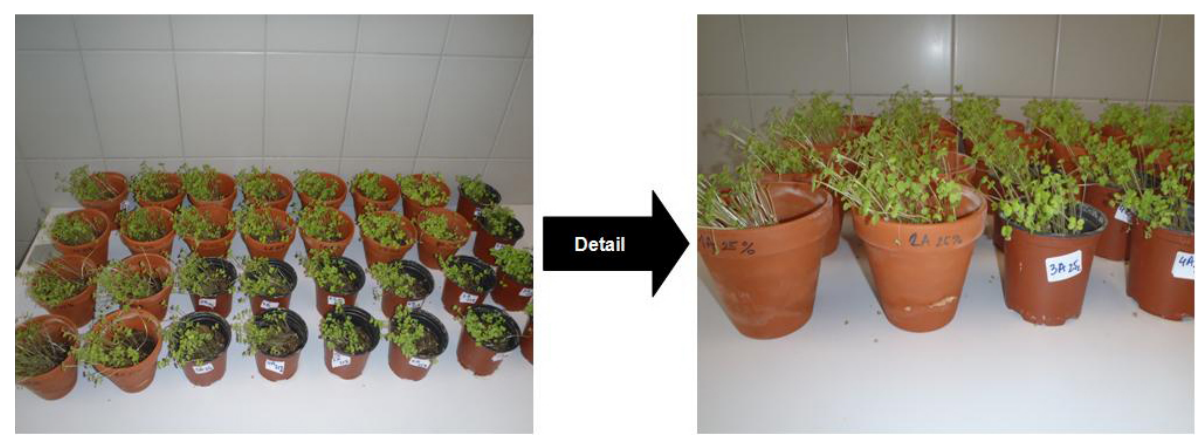

Figure 3. Samples of white mustard.

Values were calculated from the obtained data and results were evaluated. The number of sprouts (number of growing plants) occurring on samples of examined soil and on the soil from the blank experiment was compared for all mixing ratios. Germination capacity was calculated as a percentage of the corresponding values obtained from soils in the blank experiment.

Table 2 lists average values calculated from the results obtained after conducting the experiment as well as percentages of germination capacity for each sample of examined soil.

Figure 4 shows the percentage expression of germination capacity of seeds of white mustard $(25 \%$ share of soil of samples 1-8) after 14 days from the start of the experiment and after 21 days (end of the experiment).

Maximum germination capacity of seeds of white mustard at a concentration of $25 \%$ was achieved for sample 1, both in the period of 14 days (139\%) and after 21 days (137\%). The second highest value exhibited sample $2(131 \%$ after 14 days and $136 \%$ after 21 days). The third highest values were measured for samples 3 and 8, where after 14 days the germination capacity reached 106 and $111 \%$, respectively, and after 21 days the germination capacity was 110 and $107 \%$, respectively. 
Table 2. Average values and percentages of germination capacity of seeds of white mustard for examined samples.

\begin{tabular}{lrrrr}
\hline $\begin{array}{l}\text { Sample }- \\
\text { mean }\end{array}$ & \multicolumn{2}{c}{$\begin{array}{c}\text { Summary }- \\
\text { germination test }\end{array}$} & $\begin{array}{r}\text { \%umber of seeds } \\
\text { germinated }\end{array}$ \\
\hline $25 \%$ & 14 days & 21 days & 14 days & 21 days \\
1 & 85 & 88.5 & 139 & 137 \\
2 & 80 & 88 & 131 & 136 \\
3 & 64.5 & 71 & 106 & 110 \\
4 & 62.5 & 66.5 & 102 & 103 \\
5 & 60.5 & 64.5 & 99 & 100 \\
6 & 52 & 58.5 & 85 & 91 \\
7 & 48.5 & 55.5 & 80 & 86 \\
8 & 67.5 & 69 & 111 & 107 \\
Blank & 61 & 64.5 & 100 & 100 \\
$50 \%$ & 14 days & 21 days & 14 days & 21 days \\
1 & 99.5 & 99.5 & 138 & 133 \\
2 & 84.5 & 88 & 117 & 117 \\
3 & 86 & 89 & 119 & 119 \\
4 & 77.5 & 80.5 & 108 & 107 \\
5 & 88.5 & 91.5 & 123 & 122 \\
6 & 72 & 76 & 100 & 101 \\
7 & 87.5 & 89.5 & 122 & 119 \\
8 & 84.5 & 87.5 & 117 & 117 \\
Blank & 72 & 75 & 100 & 100 \\
\hline & & & & \\
\hline
\end{tabular}

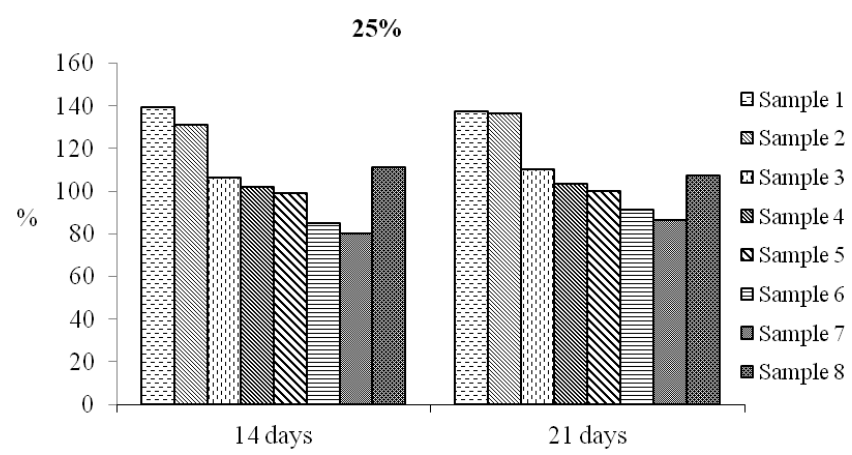

Figure 4. Comparison of the germination capacity at a concentration of $25 \%$.

Even sample 4 exhibits high values of germination capacity after 14 days $(102 \%)$ and after 21 days $(103 \%)$. The $100 \%$ germination capacity limit was reached also by sample 5 after the period of 21 days when the seed germination capacity attained $100 \%$. The lowest values of germination capacity of white mustard seeds were shown by samples 6 and 7. Germination capacity of sample 6 was 85 after 14 days and $91 \%$ after 21 days, and that of sample 7 was 80 after 14 days and $86 \%$ after 21 days.

Figure 5 shows the percentage expression of germination capacity of seeds of white mustard $(50 \%$ share of soil of samples 1-8) after 14 days from the start of the experiment and after 21 days (end of the experiment).

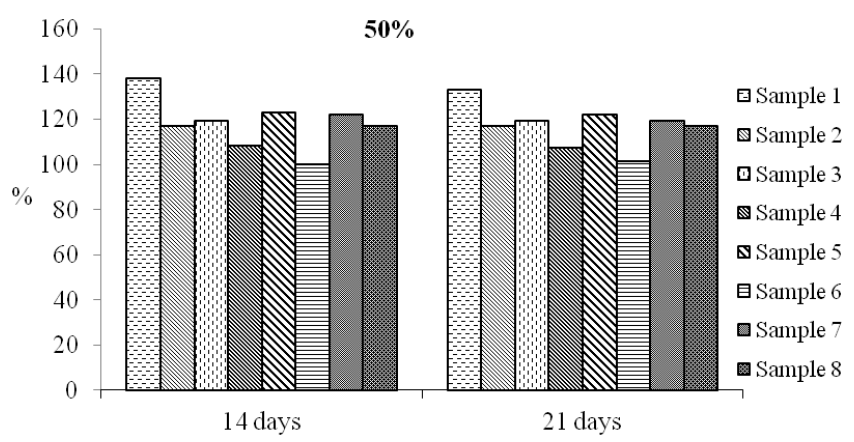

Figure 5. Comparison of the germination capacity of soil samples at a concentration of $50 \%$.

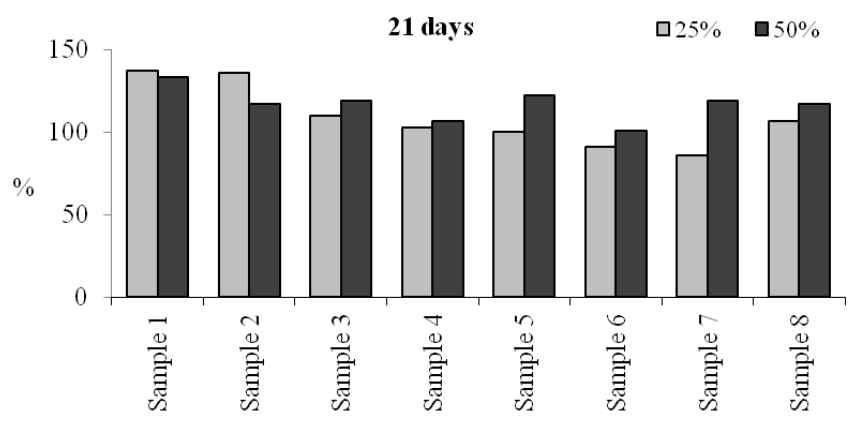

Figure 6. Results of germination capacity of white mustard seeds (at concentrations of 25 and $50 \%$ ).

At a concentration of $50 \%$, all samples (samples 1-8) reported seed germination capacity values over $100 \%$, once after 14 days and again after the 21-day period. The highest values of germination capacity occurred in sample 1 after 14 days $(138 \%)$ and after 21 days $(133 \%)$. The second highest germination capacity was observed in sample 5 , where it reached 123 after 14 days and $122 \%$ after 21 days. The third place in germination capacity of white mustard seeds was occupied by sample 7 (122 after 14 days and $119 \%$ after 21 days).

An increase in plant biomass was observed in plants growing on plates with soil samples from the landfill body and its vicinity, but no changes in appearance, slow growth, or necrotic lesions appeared. Ecotoxicity tests show that tested soils (at a concentration of 50\%) collected from the landfill body, edge of the landfill body, and its vicinity reach high percentage values of germination capacity of seeds of white mustard (101-137\%) (Fig. 6). At a concentration of $25 \%$, tested soil samples exhibit lower values of germination capacity - in particular samples 3 to 8 - yet the seed germination capacity in all eight samples of tested soils ranges between 86 and $137 \%$.

The analysis of the variance is listed in Table 3. The $p$ (ANOVA) was calculated using the Maple software. The $p$ value determines the significance level, where it is possible to reject the hypothesis that both models used are equiva- 


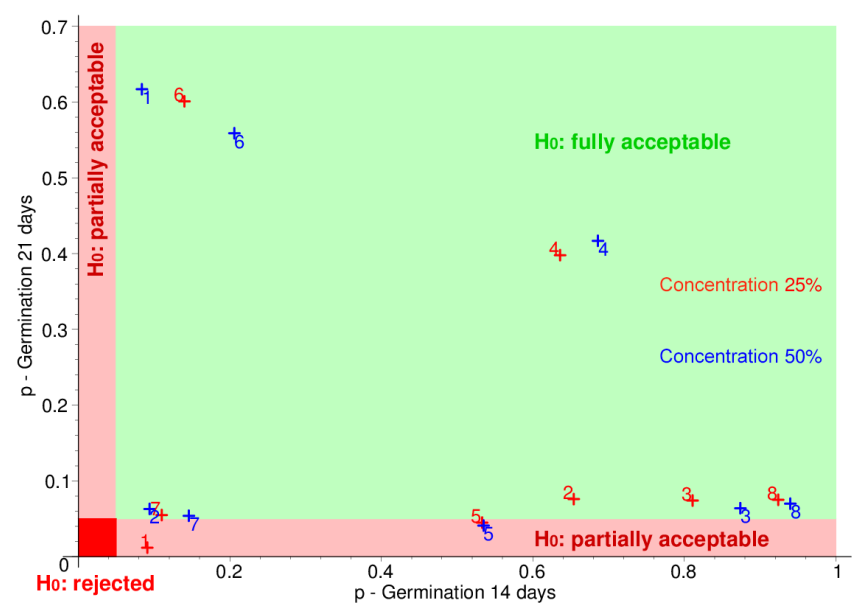

Figure 7. The values of $p$ factor (ANOVA).

lent. The $p$ value is compared with a pre-chosen constant (most commonly 0.05); when it is smaller, the equivalence of the models is rejected. Three cases where the assumption is that the behaviour of the samples is different from the behaviour of the blanks by $5 \%$ significance are marked in Table 3. Four measurements were provided for each sample two concentrations and two germination rates. Four values of $p$ are available for each sample. Not one sample can be discarded in most cases (see Fig. 7). The values of $p$ factor (ANOVA) for germination after 14 days are plotted on the $x$ axis of Fig. 7, and the values of $p$ factor (ANOVA) for germination after 21 days are plotted on the $y$ axis. The green area is the requirement for equivalent germination $-\mathrm{H}_{0}$ for samples and blanks positively satisfied on the standard range of significance $0.05-5 \%$. The pink areas indicate the failure to satisfy this condition for one of the germination rates (14 or 21) days. Sample 5 is located in this area, but it is just below the line for the 21-day germination rate, and it satisfies the 14-day germination rate. Sample 1 is also located in this area for the germination rate of 21 days but only for $25 \%$ concentration. No samples are located in the red area where hypothesis $\mathrm{H}_{0}$ can be positively rejected. Due to this it is possible to consider the assumption that $\mathrm{H}_{0}$ is not significantly affected by the landfills.

\section{Conclusions}

A phytotoxicity test was determined to assess ecotoxicity of landfill soil. Fourteen days after the establishment of the experiment, sprouts and the number of growing plants occurring in the earthen pots were counted. The data were plotted into tables, and photographs were taken to document the course of the experiment. Twenty-one days from the establishment of the experiment, the counting of sprouts and growing plants was repeated, the results recorded, and photographs taken. Results were evaluated from the acquired
Table 3. Analysis of variance.

\begin{tabular}{|c|c|c|c|c|}
\hline \multirow{3}{*}{ Sample A, B } & \multicolumn{4}{|c|}{$25 \%$} \\
\hline & \multicolumn{2}{|c|}{14 days } & \multicolumn{2}{|c|}{21 days } \\
\hline & Germination & $p$ (ANOVA) & Germination & $p(\mathrm{ANOVA})$ \\
\hline 1 & 75,91 & 0.091 & 82,95 & 0.012 \\
\hline 2 & 88,72 & 0.654 & 95,81 & 0.076 \\
\hline 3 & 66,68 & 0.811 & 68,74 & 0.074 \\
\hline 4 & 66,59 & 0.636 & 70,63 & 0.398 \\
\hline 5 & 53,68 & 0.533 & 54,75 & 0.045 \\
\hline 6 & 48,56 & 0.140 & 55,62 & 0.601 \\
\hline 7 & 56,41 & 0.110 & 61,50 & 0.055 \\
\hline \multirow[t]{2}{*}{8} & 57,78 & 0.924 & 59,79 & 0.075 \\
\hline & \multicolumn{4}{|c|}{$50 \%$} \\
\hline \multirow[t]{2}{*}{ Sample A, B } & \multicolumn{2}{|c|}{14 days } & \multicolumn{2}{|c|}{21 days } \\
\hline & Germination & $p$ (ANOVA) & Germination & $p$ (ANOVA) \\
\hline 1 & 99,100 & 0.084 & 99,100 & 0.617 \\
\hline 2 & 83,86 & 0.094 & 88,88 & 0.063 \\
\hline 3 & 81,91 & 0.874 & 85,93 & 0.064 \\
\hline 4 & 63,92 & 0.686 & 65,96 & 0.417 \\
\hline 5 & 91,86 & 0.535 & 94,89 & 0.041 \\
\hline 6 & 82,62 & 0.206 & 87,65 & 0.559 \\
\hline 7 & 84,91 & 0.146 & 87,92 & 0.054 \\
\hline 8 & 84,85 & 0.940 & 86,89 & 0.070 \\
\hline Blank & \multirow{2}{*}{\multicolumn{2}{|c|}{$\begin{array}{c}\text { Germination } 14 \text { days } \\
69,75,70,52\end{array}$}} & \multirow{2}{*}{\multicolumn{2}{|c|}{$\begin{array}{c}\text { Germination } 21 \text { days } \\
72,78,73,56\end{array}$}} \\
\hline I,II, III, IV & & & & \\
\hline
\end{tabular}

data. The number of sprouts (number of growing plants) on the soil samples and on the soil from the blank experiment was compared for all mixing ratios. Germination capacity was calculated as a percentage share of corresponding values obtained from the soil in the blank experiment. Results in the tables (germination capacity of seeds) are mean values obtained from the conducted experiment.

Plant growth test can be good protocol to assess the phytotoxicity of soil contaminated by heavy metals. White mustard is a sensitive plant that can be used as a bioindicator of heavy metals. Soil samples 1 to 8 , which were taken from the landfill body, edge of the landfill body, and its vicinity meet the limits for heavy metals $\mathrm{Co}, \mathrm{Cd}, \mathrm{Pb}$, and $\mathrm{Zn}$ specified in the applicable legislation. $\mathrm{Hg}$ and $\mathrm{Mn}$ threshold values are not established in legislation, but values have been determined for the needs of the landfill operator. For heavy metals $\mathrm{Cr}, \mathrm{Cu}$, and $\mathrm{Ni}$ some samples exceeded the threshold values, namely sample 2 , which attained the highest values of all the samples tested for $\mathrm{Cr}, \mathrm{Cu}$, and $\mathrm{Ni}$. For $\mathrm{Cr}$ and $\mathrm{Ni}$ the values were several times higher than values of the other samples.

After sample 2, the second highest values for $\mathrm{Cr}, \mathrm{Cu}$, and $\mathrm{Ni}$ were shown by sample 6 and also sample 7 (particularly for $\mathrm{Cr}$ and $\mathrm{Ni}$ ). Both of these samples exceeded the set limits, but their measured values were not as high as in the case of sample 2.

An increase in plant biomass was observed in plants growing on plates with soil samples from the landfill body and its vicinity, but no changes in appearance, slow growth, or necrotic lesions appeared. Ecotoxicity tests show that tested soils (at a concentration of $50 \%$ ) collected from the landfill 
body, edge of the landfill body, and its vicinity reach high percentage values of germination capacity of seeds of white mustard (101-137\%). At a concentration of $25 \%$, tested soil samples exhibit lower values of germination capacity - in particular samples 3 to 8 - yet the seed germination capacity in all eight samples of tested soils ranges between 86 and $137 \%$.

Author contributions. D. Adamcová, M. D. Vaverková, Z. Havlíček, and E. Břoušková designed the experiments, and D. Adamcová and M. D. Vaverková carried them out. S. Bartoň performed the analysis of the variance. M. D. Vaverková prepared the manuscript with contributions from all co-authors.

Acknowledgements. This study was supported by the IGA Internal Grant Agency Faculty of Agronomy MENDELU no. IP $13 / 2015$ "Evaluation of the hygienic quality of recycled manure solids used for dairy cattle bedding". We also thank the city of Klatovy and the Technical Services of the city of Klatovy. We would like to express our great appreciation to the management of the landfill Štěpánovice. Namely, we are very grateful to Ing. Vladimír Král, PhD and his colleagues for their assistance and their willingness to provide their time so generously.

Edited by: A. Cerdà

\section{References}

Agusa, T., Kunito, T., Nakashima, E., Minh, T. B., Tanabe, S., Subramanian, A., and Viet, P. H.: Preliminary on trace element contamination in dumping sites of municipal wastes in India and Vietnam, J. Phys. IV, 107, 21-24, 2003.

Bai, X. Y., Wang, S. J., and Xiong, K. N.: Assessing spatialtemporal evolution processes of karst rocky desertification land: indications for restoration strategies, Land Degrad. Dev., 24, 4756, 2013.

Bakare, A. A., Mosuro, A. A., and Osibanjo, O.: An in vivo evaluation of induction of abnormal sperm morphology in mice by landfill leachates, Mutat. Res.-Gen. Tox. En., 582, 28-34, 2005.

Berendse, F., van Ruijven, J., Jongejans, E., and Keesstra, S.: Loss of plant species diversity reduces soil erosion resistance, Ecosystems, 18, 881-888, 2015.

Bhattacharya, S., Gupta, K., Debnath, S., Ghosh, U. C., Chattopadhyay, D., and Mukhopadhyay, A.: Arsenic bioaccumulation in rice and edible plants and subsequent transmission through food chain in Bengal basin: a review of the perspectives for environmental health, Toxicol. Environ. Chem., 94, 429-441, 2012.

Boels, D. and Fleming, G.: Chemical time bombs from landfills: Appraisal and modelling, Land Degrad. Dev., 4, 99-405, 1993.

Brevik, E. C., Cerdà, A., Mataix-Solera, J., Pereg, L., Quinton, J. N., Six, J., and Van Oost, K.: The interdisciplinary nature of soil, Soil, 1, 117-129, doi:10.5194/soil-1-117-2015, 2015.

Chen, X. W., Tsz-Fung, Wong, J., Mo, W. Y., Man, Y.B., Wang-Wai, Ng. Ch., and Wong M. H.: Ecological Performance of the Restored South East New Territories (SENT) Landfill in Hong Kong
(2000-2012), Land Degrad. Dev., 1, 1-13, doi:10.1002/ldr.2366, 2015.

Decock, C., Lee, J., Necpalova, M., Pereira, E. I. P., Tendall, D. M., and Six, J.: Mitigating $\mathrm{N}_{2} \mathrm{O}$ emissions from soil: from patching leaks to transformative action, Soil, 1, 687-694, 2015.

El-Fadel, M., Findikakis, A. N., and Leckie, J. O.: Environmental impacts of solid waste landfilling, J. Environ. Manage., 50, 125, 1997.

Gerencsér, G., Murányi, E., Szendi, K., and Varga, C.: Ecotoxicological studies on Hungarian peloids (medicinal muds), Appl. Clay Sci., 50, 47-50, 2010.

Gorsuch, J. W., Lower, W. R., Lewis, M. A., and Wang, W.: Plants for Toxicity Assessment, ASTM STP 1115, ASTM, Philadelphia, 2, 12-28, 1991.

Hernández, A. J., Adarve, M. J., and Pastor, J.: Some impacts of urban waste landfills on Mediterranean soils, Land Degrad. Dev., 9, 21-33, 1998.

Kardanpour, Z., Jacobsen, O. S., and Esbensen, K. H.: Local versus field scale soil heterogeneity characterization - a challenge for representative sampling in pollution studies, Soil, 1, 695-705, doi:10.5194/soil-1-695-2015, 2015.

Keesstra, S. D., Geissen, V., van Schaik, L., Mosse, K., and Piiranen, S.: Soil as a filter for groundwater quality, Curr. Opin. Environ. Sustain., 4, 507-516, 2012.

Li, X. L., Gao, J., Brierley, G., Qiao, Y. M., Zhang, J., and Yang, Y. W.: Rangeland degradation on the Qinghai-Tibet Plateau: implications for rehabilitation, Land Degrad. Dev., 24, 72-80, 2013.

Loganathan, P., Hedley, M. J., and Grace, N. D.: Pasture soils contaminated with fertilizer derived cadmium and fluoride: livestock effects, Rev. Environ. Contam. T., 192, 29-66, 2008.

Mahmoud, E. and Abd El-Kader, N.: Heavy metal immobilization in contaminated soils using phosphogypsum and rice straw compost, Land Degrad. Dev., 26, 819-824, 2015.

Minh, N. H., Minh, T. B., Watanabe, M., Kunisue, T., Shinsuke, I., Tanabe, S., Sakai, S., Subramanian, A., Sasikumar, K., Viet, P. H., Tuyen, B. C., Tana, T. S., and Prudente, M. S.: Open dumping site in Asian developing countries: a potential source of polychlorinated dibenzo-p-dioxins and polychlorinated dibenzofurans, Environ. Sci. T., 37, 1493-1502, 2003.

Mol, G. and Keesstra, S. D.: Soil science in a changing world, Curr. Opin. Environ. Sustain., 4, 473-477, 2012.

OECD Guidelines for the Testing of Chemicals, Section 2, 21 pp., doi: 10.1787/9789264070066, 2006.

Pietrzak, U. and Uren, N.: Remedial options for coppercontaminated vineyard soils, Soil. Res, 49, 44-55, 2011.

Riding, M. J., Martin, F. L., Jones, K. C., and Semple, K. T.: Carbon nanomaterials in clean and contaminated soils: environmental implications and applications, Soil 1, 1-21, doi:10.5194/soil1-1-2015, 2015.

Roy, M., and Mcdonald, L. M.: Metal uptake in plants and health risk assessments in metal-contaminated smelter soils, Land Degrad. Dev., 26, 785-792, 2015.

Sacristán, D., Peñarroya, B., and Recatalá, L.: Increasing the knowledge on the management of $\mathrm{Cu}$-contaminated agricultural soils by cropping tomato (Solanum Lycopersicum L.), Land Degrad. Dev., 26, 587-595, 2015.

Smith, P., Cotrufo, M. F., Rumpel, C., Paustian, K., Kuikman, P. J., Elliott, J. A., McDowell, R., Griffiths, R. I., Asakawa, S., Bustamante, M., House, J. I., Sobocká, J., Harper, R., Pan, G., West, 
P. C., Gerber, J. S., Clark, J. M., Adhya, T., Scholes, R. J., and Scholes, M. C.: Biogeochemical cycles and biodiversity as key drivers of ecosystem services provided by soils, Soil, 1, 665-685, doi:10.5194/soil-1-665-2015, 2015.

Swati, Ghosh, P., Tanay, D. M., and Thaku, I. S.: In vitro toxicity evaluation of organic extract of landfill soil and its detoxification by indigenous pyrene-degrading Bacillus sp. ISTPY1, Int. Biodeter. Biodeg., 90, 145-151, 2014.

Thomaz, E. L. and Luiz, J. C.: Soil loss, soil degradation and rehabilitation in a degraded land area in Guarapuava (Brazil), Land Degrad. Dev., 23, 72-81, 2012.

Vaverková, M. D. and Adamcová, D.: Can vegetation indicate a municipal solid waste landfill's impact on the environment?, Pol. J. Environ. Stud., 2, 501-503, 2014a.

Vaverková, M. D. and Adamcová, D.: Heavy metals uptake by selected plant species in the landfill area of Štěpánovice, Czech Republic, Pol. J. Environ. Stud., 23, 2265-2269, 2014 b.

Vaverková, M. D. and Adamcová, D. Evaluation of landfill pollution with special emphasis on heavy metals, J. Ecol. Eng., 2, 1-6, 2014c.
Vaverková, M. D. and Adamcová, D.: Case study of landfill reclamation at Czech landfill site, Environ. Eng. Manage. J., accepted, 2016.

Wang, H.-Q., Zhao, Q., Zeng, D.-H., Hu, Y.-L., and Yu, Z.-Y.: Remediation of a magnesium-contaminated soil by chemical amendments and leaching, Land Degrad. Dev., 26, 613-619, 2015.

Wong, M. H., Chan, Y. S. G., Zhang, Ch., and Wang-Wai, Ng. Ch.: Comparison of pioneer and native woodland species growing on top of an engineered landfill, Hong Kong: restoration program, Wiley Online Library, Land Degrad. Dev., doi:10.1002/ldr.2380, 2015.

Youn-Joo, A.: Soil ecotoxicity assessment using cadmium sensitive plants, Environ. Poll., 127, 21-26, 2004. 